\title{
Analysis of Software Quality Requirements for Mobile Learning Application for High School
}

\author{
Anggy Trisnadoli and Indah Lestari
}

\begin{abstract}
Mobile applications are becoming a necessity for modern-day smartphone users. Along with the rapid growth of technological developments, the number of smartphone users are increasing. For now, smartphone users are currently dominated by teenagers with an average age of 14 to 17 , who are currently in high school. Learning activities conducted in schools have been considered well, but there are a few problems, that make obstacles in the implementation of learning activities in the classroom that can be fixed by some technology to support the process, like mobile learning. Mobile learning is an application that applies electronic learning (e-learning) in the mobile device, that application can be used by educators, students, even parents. Good mobile learning should apply all the necessary quality requirements to be able to provide good software quality. Determination of quality requirements performed according to the stage of analysis based on supporting literature and surveys of potential users who will use the application. This research focuses on learning activities in high schools. For the data collection, we get sample user from high schools that exist around the city of Pekanbaru, Indonesia by survey and interview. The data then being analyzed for proposing the quality requirement. The proposed quality requirements can be a good reference in the software quality development for good mobile learning applications.
\end{abstract}

Index Terms-Mobile application, mobile learning, e-learning, quality requirements.

\section{INTRODUCTION}

Mobile applications are becoming a necessity for modern-day smartphone users. Along with the rapid growth of technological developments, the number of smartphone users are increasing, so smartphone users are not only from certain circles but have been reached the whole range of age, occupation and social status. For now, smartphone users are currently dominated by teenagers with an average age of 14 to 17 , who are currently in high school. In high school, many problems occur in students, because their smartphones are used for inappropriate activities. If smartphone typically utilized for leisure rather than education, then smartphone phones may disrupt learning within academic, so the relationship between smartphone use and academic performance is not really good [1]. Learning activities conducted in schools has been considered well, but there are a few problems, thus making obstacles in the implementation of learning activities in the classroom, such as improper use of technology. To support the process, it is necessary to have a technology that can support that activities, like mobile learning. Mobile learning is an application that applies

Manuscript received March 3, 2018; revised May 12, 2018.

A. Trisnadoli and I. Lestari are with Information Technology Department, Politeknik Caltex Riau, Indonesia (e-mail: anggy@pcr.ac.id, indah@pcr.ac.id). electronic learning (e-learning) in the mobile device platform that used by educators, students, even parents. Good mobile learning should apply all the necessary quality requirements to be able to provide good software quality. Determination of quality requirements performed according to the stage of analysis based on supporting literature and surveys of potential users who will use the application. This research focuses on high schools that exist around the city of Pekanbaru, Indonesia. Then the proposed quality requirements can be a good reference in the software quality development for good mobile learning applications.

\section{CHARACTERISTICS OF MOBILE APPLICATION AND MOBILE LEARNING}

This research shows the quality requirements of mobile applications previously proposed by previous researchers. Followed by analyzing the quality requirements for e-learning and mobile learning, so it can be used to design a quality requirement suitable for mobile-based learning applications.

\section{A. Characteristics of Mobile Applications}

The mobile application is software that runs on mobile devices, such as PDAs, mobile phones, Tablet PC and Smartphone. Mobile applications have different characteristics with other types of apps, there are several criteria that make this type more special [2]. Usually the difference is the limitations of the mobile device itself, such as screen size, access mode, power resources and others. These things show that the characteristics of mobile applications can be studied further for use on specific requirements [3].

Software quality requirement is a collection of characteristics of a software that has been analyzed in accordance with the requirement of the software [3] that was built from various research on mobile application an game topics [4]-[7]. The quality requirements for mobile applications have been proposed by Trisnadoli et al. [8] which is a collection of specific quality requirement for mobile applications.

These quality requirements have been built by finding various aspects that can be an important reference in each mobile application requirement. With the requirement that are interconnected and interrelated, then it was considered good to be used as a reference in designing a software. The proposed quality requirements for mobile applications can be seen in Table I.

\section{B. Characteristics of e-Learning and Mobile Learning}

In the Learning Management System (LMS), there are several characteristics obtained from the LMS evaluation 
model by Kim, et al. [9] and educational technology model (ETM) by Almarashdeh et al. [10]. Based on e-learning evaluation model by Kim, et al. [9], there are seven sub factors that can be characteristic of LMS quality. However only five are associated with LMS products as a form of technology to be evaluated, such as suitability of screen and system design, ease of lecture procedure, interaction flexibility and learner test and control, various communication and test types and user access development.

While in educational technology model (ETM) by Almarashdeh, et al. [10], there are three phases of LMS development, such as system design, system usage and result. Based on these three phases, product-related quality is the phase of system design, in which the quality of the system in LMS is measured from the intrinsic features of LMS technology, including system performance and user interface. So that is usually measured are the response time, usability, availability, reliability, completeness, system flexibility and security, so it can be concluded that, the quality characteristics for e-learning products are Compatibility of screen and system design, Effectiveness in terms of ease of lecture procedure, Response time, Availability, Reliability, Completeness, System flexibility in terms of interaction, test and learner control, and Security in terms of user access.

Indah et al. [11] states that, several factors that influence the success of online learning technology used in blended learning are the characteristics of system quality for blended learning, for example flexibility, where :

1) The forms of virtual communication media are e-mail, online bulletin boards, and online communities, such as groups and blogs.

2) Blended learning should be built according to local, community or organizational needs.

3) There is room for staff to design their own classes against blended learning. In other words the teaching staff has authority over the design of the lectures that he has received.

4) Digital learning materials that can be shareable and reusable, whether it is a text, audio or video.

5) There are features of task completion, quiz and assesment.

Currently, e-learning is already running on various platforms. One is in mobile devices, called mobile learning. Mobile learning is a learning media that utilizes information technology and communication. In the concept of learning is Mobile learning brings the benefits of the availability of teaching materials that can be accessed at any time by visualizing interesting material. The term M-Learning or Mobile Learning refers to the use of mobile devices such as PDAs, mobile phones, laptops and information technology devices commonly used in teaching and learning activities [12]. [13]:

Characteristics that are important in a mobile learning are

1) Utilizing the services of electronic technology, between educators and students, among students themselves, or among educators who can communicate with relative ease with no limited by protocol matters.

2) Utilizing the advantages of computer (digital media and computer network)

3) Using self-learning materials that stored on a mobile phone or computer, so it can be accessed by educators and students anytime and anywhere.

4) Utilize the learning schedule, curriculum, learning outcomes relating to education administration that can be viewed at any time on mobile devices.

TABLE I: CHARACTERISTICS OF MOBILE [8]

\begin{tabular}{ll}
\hline \hline No & \multicolumn{1}{c}{ Characteristics } \\
\hline 1 & The displayed content is appropriate for the screen size \\
\hline 2 & The layout of the display is displayed well \\
\hline 3 & The Application runs with a short time \\
\hline 4 & The applications must be focused on it goals \\
\hline 5 & Audio and Visual that applications provided should be \\
\hline 7 & Comfortable to use \\
\hline 8 & Resources used by the application is enough to support the \\
\hline 9 & The application doesn't use much memory \\
\hline 10 & User satisfaction is stable when using the application \\
\hline 11 & Easy to learn \\
\hline 12 & Use a short time \\
\hline 13 & Task completeness \\
\hline 14 & User friendly \\
\hline 15 & The layout matches the screen size \\
\hline 16 & Gesture provided with good orientation \\
\hline 17 & The functionality that is displayed is responsive \\
\hline \hline
\end{tabular}

\section{ANALYSIS OF SOFTWARE REQUIREMENTS FOR MOBILE LEARNING APPLICATION}

Software quality requirements are obtained based on the analysis of some data collection activities. This activity was conducted in order to gather support in the form of a requirement that comes from many sources.

Data analysis comes from a collection of literature published by several researchers, and then it is combined with surveys of potential application users from high school. in this research, schools that being case study was several high school around the city of Pekanbaru, Indonesia.

The surveys have been conducted on number of respondents. These respondents are teachers who come from various high schools in the city of Pekanbaru. That survey was conducted by forming a questionnaire with an organized distribution.

The data that has been collected and then performed an analysis that shows a very interesting fact. More than $60 \%$ of respondents have never used mobile learning applications, even other electronic learning applications in schools where they teach.

It would be a challenge to continue this research. So that in gathering requirements from the users' perspective becomes more difficult and the questionnaire were deemed not good enough to use. However, this does not make the quality requirement for this application cannot be established. As an 
alternative way to be able to identify the characteristics required, the method used for this activity was changed into an interview.

The organized interviews are conducted to make the data more specific and targeted. After conducting interviews to about 50 respondents, then performed processing of data from the interview. Then we got some list of expected requirements by respondents to make a good mobile learning application. The results can be seen in Fig. 1 below.

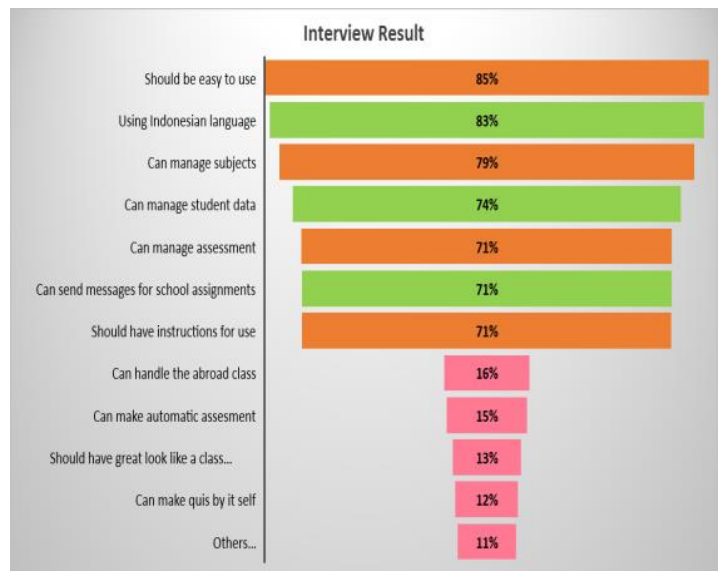

Fig. 1. Result of how mobile learning apps should be by respondents.

Based on Fig. 1, we can conclude that there are some similar dominant requirements of each aspect. After the results of the highest values were sorted out, the software requirement from the user's perspective was formed, it can be seen in Table II below.

TABLE II: USER REQUIREMENTS BASED ON INTERVIEWS RESULT

\begin{tabular}{ll}
\hline \hline No & \multicolumn{1}{c}{ Requirements } \\
\hline 1 & Mobile application should be easy to use \\
\hline 2 & Mobile application using Indonesian language \\
\hline 3 & Mobile application can manage subjects \\
\hline 4 & Mobile application can manage student data \\
\hline 5 & Mobile application can manage assessment \\
\hline 6 & Mobile application can send messages for school assignments \\
\hline \hline
\end{tabular}

Number of researchers have also conducted data collection for quality requirements for mobile learning applications, so these criteria can be used as a good source in building a quality requirement for mobile learning applications.

That criteria were mapped to determine what aspects can be a supporter in the planned quality requirements, and then formed into a list of requirements that can be seen in Table III below.

TABLE III: USER REQUIREMENT FOR MOBILE APPS BY OTHER RESEARCH

\begin{tabular}{ll}
\hline \hline No & \multicolumn{1}{c}{ Requirements } \\
\hline 1 & Mobile application should be light with not too large capacity \\
\hline 2 & Mobile application should be easy to use \\
\hline 3 & Mobile application should have appropriate learning features \\
\hline 4 & Mobile application can manage classes (lessons and students) \\
\hline 5 & Mobile application should be flexible \\
\hline 6 & Mobile application should be safe to use \\
\hline \hline
\end{tabular}

\section{PRoposed QuAlity REQUIREMENT FOR MobILE LEARNING APPLICATION}

Based on the results of the data collection, we did the mapping and combining the overall list of requirements that have been held. So the software quality requirements that had been created became reference in development of e-learning applications in mobile devices.

The proposed quality requirements for mobile learning applications for high school environments can be seen in Table IV below.

TABLE IV: PROPOSED QUALITY REQUIREMENTS FOR MOBILE LEARNING APPLICATIONS

\begin{tabular}{ll}
\hline \hline No & \multicolumn{1}{c}{ Requirements } \\
\hline 1 & Mobile application should be easy to use \\
\hline 2 & Mobile application using Indonesian language \\
\hline 3 & Mobile application can manage subjects \\
\hline 4 & Mobile application can manage student data \\
\hline 5 & Mobile application can manage assessment \\
\hline 6 & Mobile application can send messages for school assignments \\
\hline 7 & Mobile application should have instructions for use \\
\hline 9 & Mobile application should be light with not too large capacity \\
\hline 10 & Mobile application should have appropriate learning features \\
\hline 11 & Mobile application should be safe to use \\
\hline \hline
\end{tabular}

The proposed needs for quality shown in Table IV show that almost of those quality requirements can be functional and nonfunctional requirements, which can be categorized into several quality factors, such as Usability, Security, and Flexibility. It shows that these requirements can already be used as a good reference in the development of a mobile learning application for high school.

\section{CONCLUSION AND FUTURE WORKS}

Based on the results of this research, it can be concluded that the quality requirements for mobile learning applications can be obtained from various methods and sources. The quality requirements for mobile learning applications for high school was already have quality factor of Usability, Security, and Flexibility.

For future research, the proposed quality requirements can be applied in the application development process. Then it can also be tested by using the appropriate quality model for the product, so that later can show better prove, that the proposed quality requirements are good to use.

\section{ACKNOWLEDGMENT}

We would like to thank to Politeknik Caltex Riau and Kemenristekdikti to Provide this research. Also all of students and teachers of in Pekanbaru that being our respondent for this research.

\section{REFERENCES}

[1] A. Lepp, J. E. Barkley and A. C. Karpinski, "The relationship between cell phone use and academic performance in a sample of U.S. college students," SAGE Open Journal, vol. 5, no. 1, 2015 
[2] D. Franke and C. Weise, "Providing a software quality framework for testing of mobile applications," in Proc. IEEE International Conference on Software Testing, Verification and Validation, 2011, pp. 431-434.

[3] A. Trisnadoli, "Analisis kebutuhan kualitas perangkat lunak pada software game berbasis mobile," Jurnal Komputer Terapan, vol. 1, no. 2, pp. 67-74, 2015.

[4] T. H. Apperley, "Genre and game studies: Toward a critical approach to video game genres," Simulation \& Gaming, vol. 37, no. 1, pp. 6-23, 2006.

[5] A. Hussain and M. Kutar, "Usability metric framework for mobile phone application," in Proc. Postgraduate Symposium on the Convergence of Telecommunication, New York, 2008.

[6] I. Salmre, Writing Mobile Code Essential Software Engineering for Building Mobile Applications, Encarta: Addison Wesley Professional, 2005.

[7] H. Verkasalo, C. Lopez-Nicolaz, F. J. Molina-Castillo, and H. Bowman, "Analysis of users and non-users of smartphone applications," Journal Telematics and Informatics, vol. 27, no. 3, 2010.

[8] A. Trisnadoli, B. Hendradjaya and W. D. Sunindyo, "A proposal to quality model for mobile games," in Proc. International Conference on Electrical Engineering and Informatics (ICEEI) - IEEE, Denpasar, Bali, 2015, pp. 377-381.

[9] S. W. Kim and M. G. Lee, "Validation of an evaluation model for learning management systems," Journal of Computer Assisted Learning, vol. 24, no. 4, p. 284-294, 2008.

[10] I. A. Almarashdeh, N. Sahari, N. A. M. Zin, and A. Mutasem, "The success of learning management system among distance learners in Malaysian universities," Journal of Theoretical and Applied Information Technology (JATIT), pp. 80-91, 2010.

[11] I. Lestari and B. Hendradjaya, "The application model of learning management system quality in asynchronous blended learning system," in Proc. International Conference on Electrical Engineering and Computer Science (ICEECS), Denpasar, 2014, pp. 223-228.

[12] N. Setiawati, I. Kartika, and J. Purwanto, "Pengembangan mobile learning (m-learning) berbasis Moodle sebagai daya dukung pembelajaran fisika di SMA," in Proc. Seminar Nasional Fisika Dan Pendidikan Fisika, Surakarta, 2012.

[13] Soekartawi, "E-Learning di Indonesia dan Prospeknya di Masa Mendatang," Universitas Kristen Petra, Surabaya, 2013.

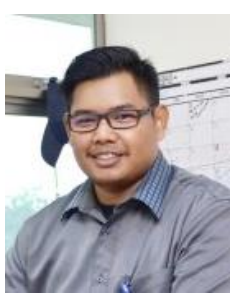

Anggy Trisnadoli obtained his B.Sc. degree in informatics engineering from Politeknik Caltex Riau in 2011, an M.Sc. also in informatics magister from Bandung Institute of Technology in 2015. He has worked as a lecturer in Politeknik Caltex Riau from 2012. Currently, he is lecturing in Information System, Information Technology Department of Politeknik Caltex Riau, Indonesia. His research interests are games, mobile application, 3D animation and multimedia software.

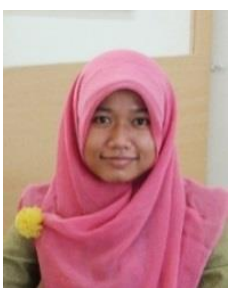

Indah Lestari is one of lecturers in Information System, Information Technology Department of Politeknik Caltex Riau, Indonesia since 2012. She also obtained her bachelor degree there and pursued master degree in 2014 at Bandung Institute of Technology, Informatics Department. Her thesis and interest area is software quality. 